\title{
Structure of parasites community in Chaetobranchopsis orbicularis (Cichlidae), a host from the Amazon River system in northern Brazil
}

\author{
Marcos Tavares-Dias $^{1} \cdot$ Marcos Sidney Brito Oliveira $^{1}$
}

Received: 5 March 2017 / Accepted: 20 June 2017 / Published online: 30 June 2017

(C) Springer-Verlag GmbH Germany 2017

\begin{abstract}
The aim of this paper was to investigate the component communities of parasites in Chaetobranchopsis orbicularis from a tributary of the Amazon River system, in Northern Brazil. In 32 fish examined, 902,551 parasites were collected, including Ichthyophthirius multifiliis, Piscinoodinium pillulare, Sciadicleithrum geophagi, Posthodiplostomum sp., Clinostomum marginatum, Echinorhynchus paranensis, Neoechinorhynchus pterodoridis, and Dolops longicauda. I. multifiliis was the dominant and abundant parasite species. The ectoparasites presented aggregate dispersion, but the endoparasites showed random dispersion pattern. Mean species richness was $4.0 \pm 1.5$ parasites, mean Brillouin diversity $(H B)$ was $0.33 \pm 0.28$, mean evenness was $0.15 \pm 0.13$, and BergerParker dominance $(d)$ was $0.85 \pm 0.17$. The species richness of parasites and HB were positively correlated with the length of hosts. There was positive correlation between the abundance of P. pillulare and length and weight, between the abundance of I. multifiliis and weight, as well as between the abundance of E. paranensis and N. pterodoridis and the length of hosts. Body condition of the hosts was not affected by moderate parasitism. The low diversity of endoparasites indicates that $C$. orbicularis is a host with low position in the food web. This is the first record of all these parasites for $C$. orbicularis.
\end{abstract}

Keywords Diversity $\cdot$ Endohelminths $\cdot$ Parasites $\cdot$ Protozoans

Marcos Tavares-Dias

marcos.tavares@embrapa.br

1 Embrapa Amapá, Rodovia Juscelino Kubitschek, km 5, 2600, Macapá, AP 68903-419, Brazil

\section{Introduction}

Family Cichlidae is a species-rich monophyletic group of brackish and freshwater Cichliformes fish. More than 1700 valid species are currently recognized, although estimates of 2000 species are not uncommon. Cichlids are widely distributed in southern continental regions including South and Central Americas, Africa, and Asia (Kullander 1998; Chakrabarty 2004; Froese and Pauly 2016; Vanhove et al. 2016). Given the extremely high number of cichlid species, there is an immense variation in virtually all aspects of their ecology, behavior, and reproductive biology. Due to large variety in morphology, ecology, and behavior of cichlids, they represent a prime model in evolutionary and parasitic research. Moreover, they are important ornamental fish and are among the most important protein sources in many parts of the world, often including low- and middle-income countries (Kullander 1998; Vanhove et al. 2016). Thus, cichlid species are an interesting group to study because of their rapid speciation, species richness, and high levels of endemism in some regions of the world (Kmentová et al. 2016). However, the great majority of studies on Amazonian cichlid fish have been were conducted on Astronotus ocellatus (Azevedo et al. 2007; Abdallah et al. 2008; Neves et al. 2013).

The majority of the Neotropical cichlids feed on a variety of invertebrates and some plant material, and specializations among those species remain little investigated. Chaetobranchopsis orbicularis Steindachner, 1875 (whiteacara), object of this study, is a zooplankton feeder, probably microcrustaceans (Soares et al. 2011; Froese and Pauly 2016). This benthopelagic fish generally inhabits macrophyte stands (Costa et al. 2011; Soares et al. 2011), habitat that can favor the presence of parasite species and infection.

C. orbicularis has distribution in South America, along the Amazon River system from the mouth of the Negro River to 
Marajó Island, and in the State of Amapá, in Brazil (Gama and Halboth 2004; Froese and Pauly 2016). This cichlid species, besides its importance in fishery (Alcântara et al. 2014), can be used in aquariums. Due to increased interest in wild fish population for aquaculture, there has been an increased interest in parasites of these fish and the diseases associated with them. Therefore, any attempt to increase the productivity in fish farms or to improve the stocks of valuable commercial fisheries in natural waters requires detailed knowledge on the parasites inhabiting the localities involved and infecting the fish populations.

The structure of parasite communities of $C$. orbicularis is still scarce; once, one infestation by Braga patagonica has been reported (Tavares-Dias et al. 2014). Factors such as host density, body size, diet, life style, and biogeographic distribution are major determinants of parasite richness in wild fish (Luque and Poulin 2004; Tavares-Dias et al. 2013; Rodrigues et al. 2014; Bellay et al. 2015). In addition, interactions between biotic and abiotic factors are essential to the composition and structure of parasite communities (Marcogliese et al. 2006; Rodrigues et al. 2014). Thus, there has been an increasing interest in population, community, and ecology of wild fish parasites (Luque and Poulin 2004; Marcogliese et al. 2006; Zrncic et al. 2009; Tavares-Dias et al. 2013; Rodrigues et al. 2014; Tavares-Dias et al. 2017). Studies on parasitic fauna of wild $C$. orbicularis may identify features of different strategies of the life cycle of endoparasites, which have complex life cycles. Such knowledge can help in intensive culture of this fish. It is welldocumented that parasites may cause infections and sometimes diseases in wild and farmed fish populations (Marcogliese et al. 2006; Martins et al. 2015). Therefore, it is essential that researchers give attention to sustainable fishery and aquaculture production. Thus, the aim of this study was to investigate the parasite communities of $C$. orbicularis of a tributary of the Amazon River system in northern Brazil.

\section{Material and methods}

\section{Fish and area of collection}

From May to August 2014, 32 specimens of $C$. orbicularis $(16.9 \pm 2.9 \mathrm{~cm}$ and $106.6 \pm 43.8 \mathrm{~g})$ were collected in the Fortaleza Igarapé basin (Fig. 1), for parasitological analysis. All fish were collected with nets of different mesh sizes (10$40 \mathrm{~mm}$ ). The identification of the parasites was performed according to Soares et al. (2011).

The Fortaleza Igarapé river is an important tributary of the Amazonas River system in the State of Amapá, eastern Amazon (Northern Brazil), and it is characterized by having a river system with extensive floodplains, constituting physical systems with a clogged river, which is drained by freshwater and connected to a main watercourse, influenced by high rainfall and tides of the Amazonas River. This tributary eutrophized by urbanization is widely used for refuge and feeding by many fish species, including cichlids (Gama and Halboth 2004; Tavares-Dias et al. 2013).

\section{Collection procedures and analysis of parasites}

In each specimen, the mouth, opercula, gills, body cavity, and gastrointestinal tract were examined to collect parasites. Gills were removed and analyzed under a microscope. To quantify metazoan parasites, each viscera was dissected separately and washed in running water and all the material retained on a $154-\mu \mathrm{m}$ mesh was examined stereomicroscopically. This work was developed according to the principles adopted by the Brazilian College of Animal Experiments (COBEA) and with authorization from Ethics Committee in the use of animals of the Embrapa Amapá (\#004 - CEUA/CPAFAP) and ICMBio (\# 23276-1). Voucher specimens were deposited at the Scientific and Technological Research Institute of the State of Amapá (IEPA), in the Scientific Collection for the Fauna of Amapá (CCFA), under accession number IEPA 40-46-P.

Previously described techniques were used to collect, fix, preserve, count, and stain the parasites (Eiras et al. 2006; Justine et al. 2012). To analyze the parasite infracommunities, the ecological terms used were those recommended by Bush et al. (1997). The following descriptors for the parasite community were calculated: the species richness, Brillouin diversity index $(H B)$, evenness $(E)$ in association with the diversity index, Berger-Parker dominance index $(d)$, and the dominance frequency (percentage of the infracommunities in which a parasite species is numerically dominant (Rohde et al. 1995; Magurran 2004), using the Diversity software (Pisces Conservation Ltd., UK). The variance-to-mean ratio (dispersion index/DI) and the discrepancy index of Poulin (D) were calculated using the Quantitative Parasitology 3.0 software to detect the distribution pattern for each parasite infracommunity (Rózsa et al. 2000) for species with prevalence $>10 \%$. The DI significance for each infracommunity was tested using the $d$-statistic (Ludwig and Reynolds 1988).

All fish were weighed $(\mathrm{g})$ and measured for total length $(\mathrm{cm})$, and then necropsied for parasitological analysis. Data of weight $(\mathrm{g})$ and total length $(\mathrm{cm})$ were used to calculate the relative condition factor $(\mathrm{Kn})$ of hosts, which was compared to the standard value $(\mathrm{Kn}=1.00)$ using the Mann-Whitney test $(U)$. Body weight $(\mathrm{Wt})$ and total length $(\mathrm{Lt})$ were also used to calculate the length-weight relationship $\left(W=a L^{b}\right)$ after logarithmic transformation of length and weight and subsequent adjustment of two straight lines, obtaining $\ln y=\ln \mathrm{A}+\mathrm{B} \ln \mathrm{x}$ (Le Cren 1951). The Spearman correlation coefficient $(r s)$ was 


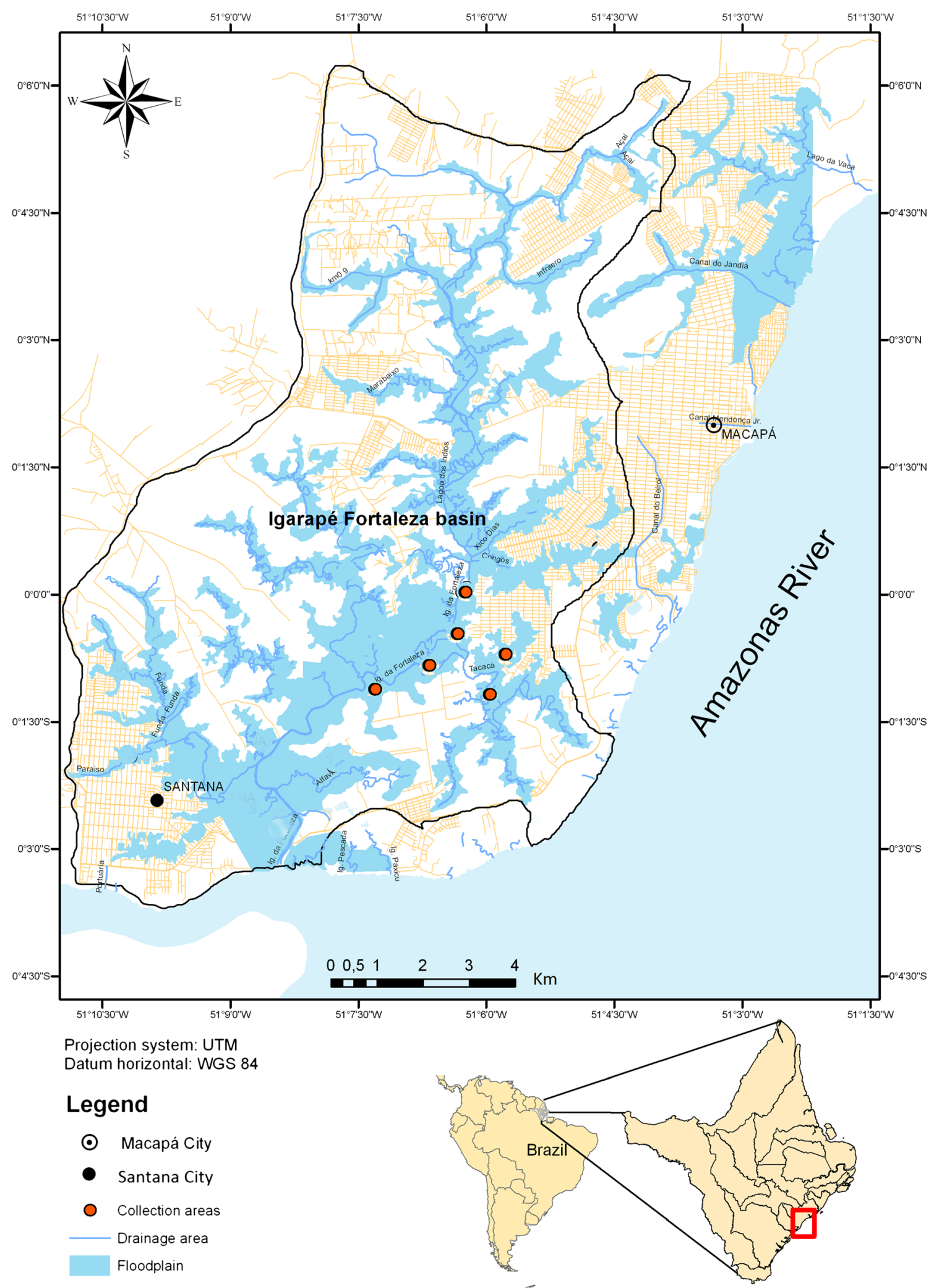

Fig. 1 Sampling site of Chaetobranchopsis orbicularis in a tributary from the Amazon River system, Brazil

applied to determine possible correlations of parasite abundance with the length and weight of the host, as well as with the parasite species richness and the Brillouin diversity (Zar 2010). 


\section{Results}

All fish were parasitized by one or more species, including Ichthyophthirius multifiliis Fouquet, 1866 (Ichthyophthiriidae); Piscinoodinium pillulare Schäperclaus, 1954, Lom, 1981 (Dinoflagellida); Sciadicleithrum geophagi Kritsky, Thatcher and Boeger, 1989 (Dactylogyridae); Posthodiplostomum Dubois, 1936 (Diplostomidae); Clinostomum marginatum Rudolphi, 1819 (Clinostomidae); Echinorhynchus paranensis Machado-Filho, 1959 (Echinorhynchidae); Neoechinorhynchus pterodoridis Thatcher, 1981 (Neoechinorhynchidae); and Dolops longicauda Heller, 1857 (Argulidae). I. multifiliis was the prevalent, abundant, and dominant parasite, and C. marginatum and D. longicauda were the least prevalent and abundant parasites (Tables 1 and 2). These parasites had an aggregated dispersion pattern, except for E. paranensis and $N$. pterodoridis, which presented random dispersion (Table 2).

In $C$. orbicularis, there was a higher diversity among the helminth species. The species richness varied from two to seven parasites per host and the Brillouin diversity varied from 0.001 to 0.71 (Table 3). Positive correlation was found between the length $(r s=0.470, p=0.007)$ and the species richness of parasites and the Brillion diversity ( $r s=0.483$, $p=0.005)$. In addition, there was a predominance of hosts infected with three to four parasites (Fig. 2).

For $C$. orbicularis, the equation of the relationship between weight $(\mathrm{W})$ and length $(\mathrm{L})\left(\mathrm{Wt}=0.1451 \mathrm{Lt}^{2.311}\right.$, $\left.r^{2}=0.701\right)$ was negative allometric, indicating greater increase in body weight than in size. The Kn of the hosts $(\mathrm{Kn}=0.997)$ was not different $(t=-0.215)$ from the standard value $(\mathrm{Kn}=1.000)$.

There was a positive correlation between the abundance of $P$. pillulare and the length and weight of hosts. A positive correlation was observed between the abundance of I. multifiliis and the weight of the hosts. A positive correlation was found between the abundance of $E$. paranensis and $N$. pterodoridis and the length of the hosts (Table 4).

\section{Discussion}

The component community of $C$. orbicularis consisted of two species of Protozoa, one Monogenoidea, two Digenea, two Acanthocephala, and one Crustacea. The dominance was of protozoans I. multifiliis followed by P. pillulare, both ectoparasites with direct life cycle. However, the high diversity was verified for helminth species, including ecto- and endoparasites, with a dominance of $E$. paranensis and $N$. pterodoridis among the endohelminths, due to life mode and diet components of this omnivorous and benthopelagic host (Costa et al. 2011; Soares et al. 2011; Froese and Pauly 2016). Furthermore, the ectoparasites community showed an

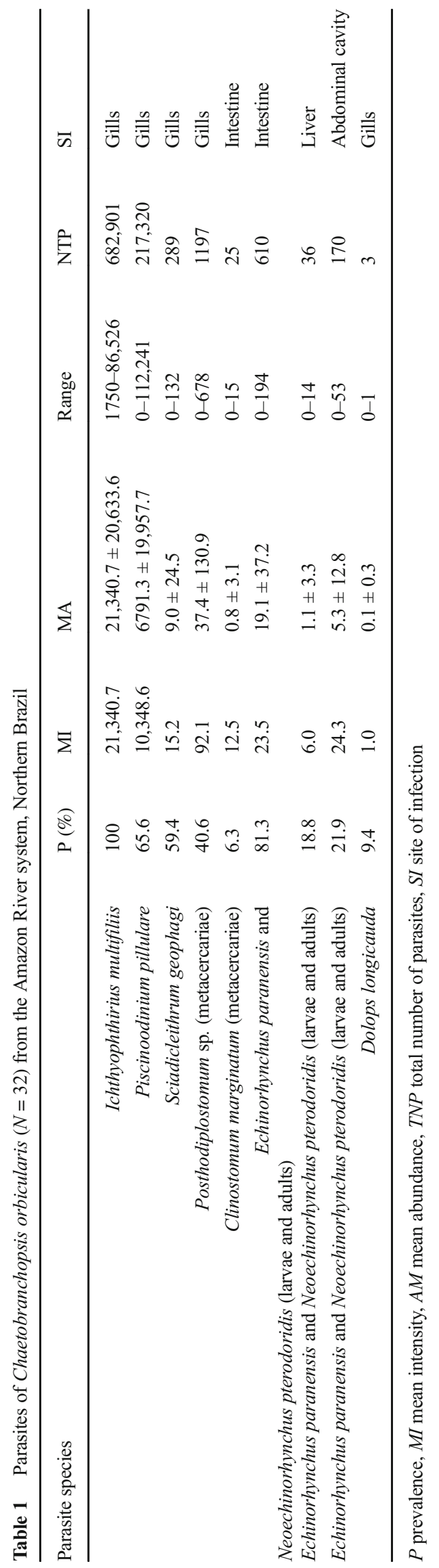


Table 2 Dispersion index (DI), $d$-statistic and discrepancy index (D) for the parasite infracommunities of Chaetobranchopsis orbicularis from the Amazon River system, Northern Brazil

\begin{tabular}{lllll}
\hline Parasites & DI & $d$ & D & FD (\%) \\
\hline Ichthyophthirius multifiliis & 3.84 & 3.10 & 0.34 & 0.76 \\
Piscinoodinium pillulare & 3.28 & 2.78 & 0.50 & 0.24 \\
Sciadicleithrum geophagi & 3.37 & 2.41 & 0.58 & 0.0003 \\
Posthodiplostomum sp. & 3.73 & 2.94 & 0.72 & 0.0013 \\
Echinorhynchus paranensis and Neoechinorhynchus pterodoridis & 2.86 & 1.60 & 0.43 & 0.0007 \\
Neoechinorhynchus pterodoridis & 2.55 & 1.07 & 0.86 & 0.0002 \\
\hline
\end{tabular}

$F D$ frequency of dominance aggregated dispersion pattern, which is common among parasite communities of freshwater fish (Poulin 2013; TavaresDias et al. 2013; Rodrigues et al. 2014; Tavares-Dias et al. 2017). This dispersion pattern is for mitigating harm to host populations and reducing interspecific competition among parasite species. However, the endoparasites community presented a random distribution pattern, which can be due to the reduced opportunity to colonize this host, as well as to its pathological effects, once pathogenic parasite species are frequently less aggregated (Dobson 1990; Moller 2006; Neves et al. 2013; Tavares-Dias et al. 2017).

High infection levels by $P$. pillulare and I. multifiliis were found in the gills of $C$. orbicularis. Both protozoan species may infect wild and farmed freshwater fish populations in various parts of the world, because both parasites have no parasitic specificity (Zrncic et al. 2009; Raissy et al. 2010; Tavares-Dias et al. 2013; Rodrigues et al. 2014; Bittencourt et al. 2014; Martins et al. 2015). High susceptibility to infections by such species of protozoans occurs in host fish of low environmental conditions, which favor the reproduction of these parasites and decreases the resistance of hosts due to stress. Diseases caused by both these parasites are highly contagious and spread rapidly from one fish to another (Raissy et al. 2010; Martins et al. 2015), which may cause economic losses for the growing fishery and aquaculture industry.

Monogenoideans may be highly specific to their hosts, i.e., they parasitize a particular fish species or closely related species either of the same genus or family. For instance, species of Gussevia Kohn \& Paperna, 1964 and Sciadicleithrum Kritsky, Thatcher \& Boeger, 1989 parasitize species of Neotropical

Table 3 Descriptors of diversity for parasite communities of Chaetobranchopsis orbicularis $(N=32)$ from the Amazon River system, Northern Brazil

\begin{tabular}{ll}
\hline Diversity index & Mean \pm SD (range) \\
\hline Species richness & $4.0 \pm 1.5(2-7)$ \\
Brillouin $(H B)$ & $0.33 \pm 0.28(0.001-0.71)$ \\
Evenness $(E)$ & $0.15 \pm 0.13(0.0006-0.32)$ \\
Berger-Parker $(d)$ dominance & $0.85 \pm 0.17(0.54-1.00)$ \\
\hline
\end{tabular}

Cichlidae known as acaras (Yamada et al. 2009; Braga et al. 2014). Thus, more than 11 species of Sciadicleithrum infect 7 species of cichlids from South America, and 8 species of this genus infect 22 hosts from Central America and the Southeast Mexico (Yamada et al. 2009). In the gills of $C$. orbicularis, $S$. geophagi were found, and at infection levels lower than that of Sciadicleithrum satanopercae Yamada, Takemoto, Bellay \& Pavanelli, 2009 for Satanoperca pappaterra from the Paraná River floodplain (Yamada et al. 2009).

In $C$. orbicularis gills, the infection levels by metacercariae of Posthodiplostomum sp. were higher than of C. marginatum metacercariae in the intestine. Both parasites have heteroxenic life cycle involving mollusk and fish as intermediate hosts and fish-eating birds as definitive hosts (Pinto et al. 2015; TavaresDias et al. 2017). N. pterodoridis and acanthocephalan of Pterodoras granulosus, a Doradidae from the Amazon (Thatcher 1981) was found in C. orbicularis in this study. Larvae and adults of $N$. pterodoridis occurred in the intestine, liver, and abdominal cavity of $C$. orbicularis, but the intestine was the site with a higher infection level together with E. paranensis, an acanthocephalan with wide geographic distribution and no parasitic specificity (Bittencourt et al. 2014). Therefore, $C$. orbicularis is a new definitive host for both $N$. pterodoridis and E. paranensis.

Variation in the physiological status of host fish populations, such as variation in body condition due to nutritional deficiency can lead to parasitic infections (Guidelli et al. 2011;

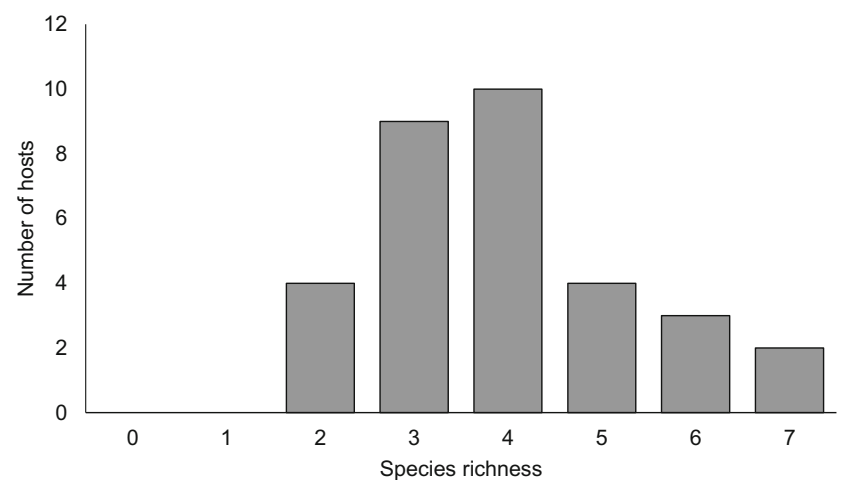

Fig. 2 Species richness of parasites in Chaetobranchopsis orbicularis from the Amazon River system, Northern Brazil 
Rodrigues et al. 2014). Nevertheless, in C. orbicularis infected with ecto- and endoparasites, the condition factor indicated good body condition. The influence of body size of the host fish on parasites plays an important role in determining the infection susceptibility of hosts, growth and development of parasites, and consequently has great implications in the dynamics of infection and the ecology of host-parasites interactions (Poulin 1999; Luque and Poulin 2004; Rodrigues et al. 2014, Tavares-Dias et al. 2017). Parasite abundance, diversity, and species richness increased with the increase in body size of $C$. orbicularis, for some few species. Thus, this indicates that host body size is an important determinant of variations in abundance and parasite species richness among this host population. Furthermore, the lack of relationship between the abundance of $S$. geophagi and host body size is because this ectoparasite has direct life cycle, and environmental conditions could influence infection pattern.

In summary, $C$. orbicularis had a component community of parasites characterized by low species richness, low diversity, and low evenness, and with the presence of endohelminths in larval stage, indicating that this host fish has mollusks and crustaceans composing its diet. Furthermore, the low richness of endoparasites with heteroxenic life cycle suggests that this host has a low position in food the web, as expected. This was the first study on the ecological diversity of $C$. orbicularis.

Acknowledgments Marcos Tavares-Dias was granted (\# 303013/ 2015-0), a Research fellowship from the National Council for Scientific and Technological Development (CNPq, Brazil). M. S. B. Oliveira was granted a Masters scholarship from CNPq.

\section{References}

Abdallah VD, Azevedo RK, Luque JL (2008) Notes on the morphology of two species of Gussevia Kohn e Paperna (Monogenea: Dactylogyridae) parasite on Astronotus ocellatus (Agassiz) (Perciformes: Cichlidae) from Brazil. Panamjas 3:101-104

Azevedo RK, Abdallah VD, Luque JL (2007) Ecologia da comunidade de metazoários do apariari Astronotus ocellatus (Cope, 1872) (Perciformes: Cichlidade) do Rio Gandu, Estado do Rio de Janeiro, Brasil. Rev Brasil Parasitol Vet 16:15-20

Bellay S, Oliveira EF, Almeida-Neto M, Mello MAR, Takemoto RM, Luque JL (2015) Ectoparasites and endoparasites of fish form networks with different structures. Parasitology 142:901-909

Bittencourt LS, Pinheiro DA, Cárdenas MQ, Fernandes BMM, TavaresDias M (2014) Parasites of native Cichlidae populations and invasive Oreochromis niloticus (Linnaeus, 1758) in tributary of Amazonas River (Brazil). Braz J Vet Parasitol 23:44-54

Braga MP, Araújo SBL, Boeger WA (2014) Patterns of interaction between Neotropical freshwater fishes and their gill Monogenoidea (Platyhelminthes). Parasitol Res 113:481-490

Bush AO, Lafferty KD, Lotz JM, Shostak W (1997) Parasitology meets ecology on its own terms: Margolis et al. Revisited J Parasitol 83: $575-583$

Chakrabarty P (2004) Cichlid biogeography: comment and review. Fish Fish 5:97-119 
Costa DI, Romagnoli CF, Carmo LLT, Ribas C, Leite RG, Zuanon ASJ (2011) Ictiofauna associada a bancos de herbáceas aquáticas flutuantes na ilha da Marchantaria, Rio Solimões, Amazônia central, Brasil. Rev Colomb Cienc Anim 3:148-156

Dobson AP (1990) Models of multi-species parasites-host communities. In: Esch GW, Bush AO, Aho J (eds) Parasite communities: patterns and process. Chapman and Hall, New York, pp 261-287

Froese R, Pauly D. Editors. 2016. FishBase. World Wide Web electronic publication.www.fishbase.org, version (10/2016).

Gama CS, Halboth DA (2004) Ictiofauna das ressacas das bacias do Igarapé da Fortaleza e do Rio Curiaú. In: Takiyama LR, Silva AQ (orgs.) Diagnóstico das ressacas do estado do Amapá: bacias do Igarapé da Fortaleza e Rio Curiaú, Macapá-AP. CPAQ/IEPA e DGEO/SEMA, pp 23-52.

Guidelli G, Tavechio WLG, Takemoto RM, Pavanelli GC (2011) Relative condition factor and parasitism in anostomid fishes from the floodplain of the Upper Paraná River, Brazil. Vet Parasitol 177:145-151

Justine JL, Marine J, Briand MJ, Bray RA (2012) A quick and simple method, usable in the field, for collecting parasites in suitable condition for both morphological and molecular studies. Parasitol Res 111:341-351

Kmentová N, Gennar M, Koblmüller S, Vanhove MPM (2016) First insights into the diversity of gill monogeneans of 'Gnathochromis' and Limnochromis (Teleostei, Cichlidae) in Burundi: do the parasites mirror host ecology and phylogenetic history? Peer J 4:e1629. doi:10.7717/peerj.1629

Kullander SO (1998) A phylogeny and classification of the South American Cichlidae (Teleostei: Perciformes). In: Malabarba LR, Reis RE, Vari RP, Lucena ZMS, Lucena CAS (eds) Phylogeny and classification of Neotropical fishes. Edipucrs, Porto Alegre, pp 461-498

Le Cren ED (1951) The length-weight relationship and seasonal cycle in gonadal weight and condition in the perch (Perca fluviatilis). J Anim Ecol 20:201-219

Ludwig JA, Reynolds JF (1988) Statistical ecology: a primer on methods and computing. Wiley-Interscience Pub, New York

Luque JL, Poulin R (2004) Use of fish as intermediate hosts by helminth parasites: a comparative analysis. Acta Parasitol 49:353-361

Marcogliese DJ, Gendron AD, Plante C, Fournier M, Cyr D (2006) Parasites of spottail shiners (Notropis hudsonius) in the St. Lawrence River: effects of municipal effluents and habitat. Can J Zool 84:1461-1481

Magurran AE (2004) Measuring biological diversity. Blackwell Science, Oxford

Martins ML, Cardoso L, Marchiori N, Pádua SB (2015) Protozoan infections in farmed fish from Brazil: diagnosis and pathogenesis. Braz J Vet Parasitol 24:1-20

Moller AP (2006) Parasitism and the regulation oh host populations. In: Thomas F, Renaud F, Guégan JF (eds) Parasitism and ecosystems. Oxford University Press, New York, pp 43-53
Neves LR, Pereira FB, Tavares-Dias M, Luque JL (2013) Seasonal influence on the parasite fauna of a wild population of Astronotus ocellatus (Perciformes: Cichlidae) from the Brazilian Amazon. J Parasitol 99:718-721

Pinto HA, Caffara M, Fioravanti ML, Melo AL (2015) Experimental and molecular study of cercariae of Clinostomum sp. (Trematoda: Clinostomidae) from Biomphalaria spp. (Mollusca: Planorbidae) in Brazil. J Parasitol 101:108-113

Poulin R (1999) Body size vs abundance among parasite species: positive relationships? Ecography 22:246-250

Poulin R (2013) Explaining variability in parasite aggregation levels among host samples. Parasitology 140:541-546

Raissy M, Ansari M, Moumeni M, Goudarzi MA, Sohrabi HR, Rashedi M (2010) An epizootic of ichthyophthiriasis among fishes in Armand River, Iran. J Cell Anim Biol 4:151-153

Rohde K, Hayward C, Heap M (1995) Aspects of the ecology of metazoan ectoparasites of marine fishes. J Parasitol 25:945-970

Rodrigues MNG, Dias MKR, Marinho RGB, Tavares-Dias M (2014) Parasites diversity of Osteoglossum bicirrhosum, an Osteoglossidae fish from amazon. Neotrop Helminthol 8:383-391

Rózsa LJ, Reiczigel J, Majoros G (2000) Quantifying parasites in samples of hosts. J Parasitol 86:228-232

Soares MGM, Costa EL, Siqueira-Souza FK, Anjos HDB, Yamamoto KC, Freitas CEC (2011) Peixes de lagos do médio Rio Solimões, 2a edn. Instituto Piatam, Manaus

Thatcher VE (1981) Neoechinorhynchus pterodoridis n. sp. (Acanthocephala: Neoechinorhynchidae) do bacu liso (Pterodoras granulosus) da Amazônia Brasileira. Acta Amaz 11:445-448

Tavares-Dias M, Neves LR, Pinheiro DA, Oliveira MSB, Marinho RGB (2013) Parasites in Curimata cyprinoides (Characiformes: Curimatidae) from eastern Amazon, Brazil. Acta Sci Biol Sci 35: 595-601

Tavares-Dias M, Gonçalves RA, Oliveira MSB, Neves LR (2017) Ecological aspects of the parasites in Cichlasoma bimaculatum (Cichlidae), ornamental fish from the Brazilian Amazon. Acta Biol Colomb 22:175-180

Vanhove MPM, Hablützel PI, Pariselle A, Šimková A, Huyse T, Raeymaekers JAM (2016) Cichlids: a host of opportunities for evolutionary parasitology. Trends Parasitol 32:820-832

Yamada FH, Takemoto RM, Bellay S, Pavanelli GC (2009) Two new species of Sciadicleithrum (Monogenea, Dactylogyridae) parasites of Neotropical cichlid fishes from the Paraná River, Brazil. Acta Parasitol 54:6-11

Zar JH (2010) Biostatistical analysis, 5th edn. Prentice Hall, Upper Saddle River

Zrncic S, Oraic D, Sostari B, Caleta M, Bulj I, Zanella D, Surmanovic D (2009) Occurrence of parasites in Cobitidae from Croatian rivers draining into two different watersheds. J Appl Ichthyol 25:447-450 